\title{
COMPARISON BETWEEN A CLINICAL SHORT-CUT METHOD AND A PRECISE LABORATORY ESTIMATION OF INTRAPULMONARY SHUNT AND A-aDo
}

\author{
Louis Fournier and Diane Major
}

\begin{abstract}
This study shows the application to 20 patients of a very simple formula to estimate $A-\mathrm{aD}_{\mathrm{O}_{2}}$ and intrapulmonary shunt, from data commonly available in patients with oxygenation disorders. The values obtained by the "clinical short cut" method and the more sophisticated one are in statistically significant correlation.
\end{abstract}

Key Words: Measurement Techniques; Lung, Shunting.

RESPIRATORY INSUFFICIENCY is mainly the consequence of hypoventilation or impairment of the ventilation perfusion-ratio. Hypoventilation by itself is relatively easy to diagnose. On the other hand, impairment of the ventilation-perfusion ratio is more intricate to evaluate. It is seen with an intrapulmonary shunt ${ }^{1}$ or imbalance of the alveolo-arterial gradient. These two parameters can be estimated precisely with proper laboratory instrumentation. ${ }^{2}$ This apparatus is not generally available to the clinician. However it would certainly be helpful to be able to estimate these two values accurately ${ }^{3}$ from clinical data commonly measured. We have tried to find a method of estimation which will give results close to the values which would be obtained by sophisticated laboratory measurements.

\section{Material and Methods}

The study was conducted on twenty intensive care adult patients who needed respiratory assistance following major surgery or for severe cardiac disease.

All these patients had a catheterisation of the pulmonary artery with a Swan-Ganz catheter. Radial artery puncture was done on each of them for blood gas analysis using an Astrup Radiometer blood analyser. Total haemoglobin was determined by Coleman jr. spectrophotometer.

Louis Fournier, M.D., F.R.C.P.(C), Professor, Department of Anaesthesiology Laval University and Chief Anaesthetist, Centre Hospitalier de l'Université Laval; Diane Major, B.Sc., Biologist, Anaesthesia Laboratory, Centre Hospitalier de l'Université Laval, Québec, Québec.

\section{A-aDO $\mathrm{O}_{2}$ (Precise Laboratory Estimation)}

Formula: Alveolo-arterial gradient was obtained using the following equation:

$$
\mathrm{A}-\mathrm{aDO}_{2}=\mathrm{PA}_{\mathrm{O}_{2}}-\mathrm{Pa}_{\mathrm{O}_{2}}
$$

where

$\mathrm{PA}_{\mathrm{O}_{2}}=\mathrm{PI}_{\mathrm{O}_{2}}-\mathrm{Pa}_{\mathrm{CO}_{2}}\left[\frac{\mathrm{FI}_{\mathrm{O}_{2}}\left(1-\mathrm{FI}_{\mathrm{O}_{2}}\right)}{\mathrm{R}}\right]$

(alveolar air equation). ${ }^{4}$

For $\mathrm{PI}_{\mathrm{O}_{2}}, \mathrm{R}$ and $\mathrm{F}_{\mathrm{O}_{2}}$ determinations, respiratory gases were sampled with $50 \mathrm{ml}$ glass syringes, previously washed with mineral oil or lactic acid. The inspiratory gases were sampled directly in the inspiratory tube of the MA-1 ventilator with the syringe and expiratory gases were gathered from a five litre bag to insure adequate mixing of the expiratory air. This bag was attached to a three-way directional valve placed in the expiratory tube, before the MA-1 manifold, in order to have pure expiratory gases. The few patients who were not intubated were connected to this system through a facial mask. Expiratory minute volume was measured with a Wright spirometer at flow corresponding to normal ventilation for each patient.

\section{A-aDo ("Clinical Short-Cut" Method)}

For the clinical estimation of $\mathrm{A}-\mathrm{aDO}_{2}$, we used the same equation as used for the precise laboratory estimation but with the following simplification ${ }^{5}$ of the alveolar air equation:

$$
\mathrm{PA}_{\mathrm{O}_{2}}=\mathrm{PB}-\mathrm{PH}_{2} \mathrm{O}-\mathrm{PCO}_{2}-\mathrm{PN}_{2}
$$

This last equation requires only clinical data commonly available: 
TABLE I

Commonly Measured Values NeEded to Estimate A-aDo 2 AND Q́s/Q்t

\begin{tabular}{|c|c|c|c|c|c|c|}
\hline \multirow{2}{*}{$\begin{array}{l}\# \\
\text { pt }\end{array}$} & \multirow[b]{2}{*}{$\mathrm{Fl}_{\mathrm{O}_{2}}$} & \multicolumn{2}{|c|}{$\mathrm{Pa}_{0_{2}}$} & \multicolumn{2}{|c|}{$\mathrm{Pa}_{\mathrm{CO}_{2}}$} & \multirow{2}{*}{$\begin{array}{l}\mathrm{Hb} \\
\mathrm{g} \%\end{array}$} \\
\hline & & $\mathrm{mmHg}$ & $\mathrm{kPa}$ & $\mathrm{mmHg}$ & $\mathrm{kPa}$ & \\
\hline 1 & 0.50 & 73 & 9.71 & 37.2 & 4.95 & 10.0 \\
\hline 2 & 0.30 & 90 & 11.97 & 34.2 & 4.55 & 13.5 \\
\hline 3 & 0.35 & 90 & 11.97 & 36.5 & 4.85 & 10.5 \\
\hline 4 & 0.30 & 89 & 11.84 & 31 & 4.12 & 10.4 \\
\hline 5 & 0.60 & 49 & 6.52 & 32.6 & 4.34 & 9.5 \\
\hline 6 & 0.80 & 57 & 7.58 & 31.8 & 4.23 & 4.8 \\
\hline 7 & 0.60 & 46 & 6.12 & 25 & 3.33 & 9.0 \\
\hline 8 & 0.30 & 81 & 10.77 & 20.9 & 2.78 & 8.1 \\
\hline 9 & 0.21 & 85 & 11.31 & 30.5 & 4.06 & 13.2 \\
\hline 10 & 0.21 & 53 & 7.05 & 28.2 & 3.75 & 9.0 \\
\hline 11 & 0.30 & 80 & 10.64 & 45.2 & 6.01 & 8.7 \\
\hline 12 & 0.40 & 95 & 12.64 & 35.3 & 4.69 & 12.2 \\
\hline 13 & 0.40 & 100 & 13.30 & 31.3 & 4.16 & 10.7 \\
\hline 14 & 0.40 & 78 & 10.37 & 36.8 & 4.89 & 10.0 \\
\hline 15 & 0.40 & 83 & 11.04 & 26.1 & 3.47 & 10.0 \\
\hline 16 & 0.40 & 70 & 9.31 & 36.3 & 4.83 & 11.0 \\
\hline 17 & 0.30 & 68 & 9.04 & 25.5 & 3.39 & 11.0 \\
\hline 18 & 0.30 & 85 & 11.31 & 28 & 3.72 & .9 .4 \\
\hline 19 & 0.21 & 96 & 12.77 & 45 & 5.99 & 12.7 \\
\hline 20 & 0.45 & 75 & 9.98 & 35 & 4.66 & 11.5 \\
\hline
\end{tabular}

Barometric pressure $=\mathrm{PB}=760 \mathrm{mmHg}$ (101 kPa).

Alveolar water vapor pressure $=\mathrm{PH}_{2} \mathrm{O}=47$ $\mathrm{mmHg}(6.2 \mathrm{kPa})$.

Blood carbon dioxide $=$ measured $\mathrm{PCO}_{2}$.

Alveolar air nitrogen tension $=\mathrm{PN}_{2}=713 \mathrm{~mm} \mathrm{Hg}$ $(94.8 \mathrm{kPa}) \times \mathrm{FI}_{\mathrm{N}_{2}}\left(\mathrm{FI}_{\mathrm{N}_{2}}=1-\mathrm{FI}_{\mathrm{O}_{2}}\right)$

\section{Shunt (Precise Laboratory Estimation)}

Formula: Intrapulmonary shunt was obained using the following equation:

$$
\frac{\dot{\mathrm{Q}} \mathrm{s}}{\mathrm{Q} t}=\frac{\mathrm{Cc}_{\mathrm{O}_{2}}-\mathrm{Ca}_{\mathrm{O}_{2}}{ }^{6}}{\mathrm{Cc}_{\mathrm{O}_{2}}-\mathrm{C}_{\mathrm{v}_{2}}}
$$

In order to know the oxygen contents for the intrapulmonary shunt, oxygen saturations were determined photometrically with an OSMIRadiometer for arterial blood and for mixed venous blood from pulmonary artery. The pulmonary oxygen content was calculated using the alveolar air equation.

\section{Shunt ("Clinical Short-Cut" Method)}

For the clinical estimation of intrapulmonary shunt the usual calculation was simplified by arbitrarily setting the $\mathrm{C}_{\mathrm{O}_{2}} 3.5 \mathrm{ml}$ less than $\mathrm{Ca}_{\mathrm{O}_{2}}{ }^{7}$ We also assumed the $\mathrm{PA}_{\mathrm{O}_{2}}$ to be proportional to $\mathrm{FI}_{\mathrm{O}_{2}}$ as we did when estimating $\mathrm{A}-\mathrm{aDo} \mathrm{O}_{2}$. The oxygen saturation, which in this case is not directly measured, was obtained from the nomo- gram for oxygen-haemoglobin dissociation curve (Severinghaus). ${ }^{8}$ One gram of hae moglobin was considered to carry $1.37 \mathrm{ml}$ of oxygen. 9

The following example will illustrate the calculations of $\mathrm{A}-\mathrm{aDO}_{2}$ and intrapulmonary shunt starting from simple available parameters:

$\mathrm{Hb}=9.0 \mathrm{~g} / \mathrm{dl}$

$\mathrm{Pa}_{\mathrm{O}_{2}}=46 \mathrm{mmHg}(6.1 \mathrm{kPa})$

$\mathrm{O}_{2}$ sat. $=0.81$ (Severinghaus)

$\mathrm{Pa}_{\mathrm{CO}_{2}}=25 \mathrm{mmHg}(3.3 \mathrm{kPa})$

$\mathrm{FI}_{\mathrm{O}_{2}}=\mathbf{0 . 6 0}$.

"Clinical short cut" estimations are calculated as follows:

\section{(1) Alveolo-Arterial Difference}

$$
\begin{aligned}
\mathrm{A}-\mathrm{aDO}_{2} & =\mathrm{PA}_{\mathrm{O}_{2}}-\mathrm{Pa}_{\mathrm{O}_{2}} \\
& =\left[\mathrm{PB}-\mathrm{PH}_{2} \mathrm{O}-\mathrm{PCO}_{2}-\mathrm{PN}_{2}\right]-\mathrm{Pa}_{\mathrm{O}_{2}} \\
& =[760-47-25-(713 \times 0.40)]-46 \\
& =[402.8]-46 \\
& =356.8 \mathrm{mmHg}(47.4 \mathrm{kPa})
\end{aligned}
$$

(2) Intrapulmonary Shunt

$$
\dot{\mathrm{Q}} \mathrm{s} / \dot{\mathrm{Q}} \mathrm{t}=\frac{\mathrm{Cc}_{\mathrm{O}_{2}}-\mathrm{Ca}_{\mathrm{O}_{2}}}{\mathrm{Cc}_{\mathrm{O}_{2}}-\overline{\mathrm{C}}_{\mathrm{O}_{2}}}
$$

Keeping in mind that blood $\mathrm{O}_{2}$ content $(\mathrm{C})$ is obtained from blood $\mathrm{Hb}$ content $(\mathrm{Hb})$ and $\mathrm{O}_{2}$ saturation $\left(\mathrm{SO}_{2}\right)$

$$
\mathrm{C}=\left(\mathrm{Hb} \times 1.37 \times \mathrm{So}_{2}\right)+\left(\mathrm{Po}_{2} \times 0.003\right)
$$




\begin{tabular}{|c|c|c|c|c|}
\hline \multirow{2}{*}{$\begin{array}{l}\# \\
\text { pt }\end{array}$} & \multicolumn{2}{|c|}{$\begin{array}{c}\text { A-aDo } \\
\text { "short cut" } \\
\text { method }\end{array}$} & \multicolumn{2}{|c|}{$\begin{array}{c}\mathrm{A}-\mathrm{aDO}_{2} \\
\text { laboratory precise } \\
\text { method }\end{array}$} \\
\hline & $\mathrm{mmHg}$ & $\mathrm{kPa}$ & $\mathrm{mmHg}$ & $\mathrm{kPa}$ \\
\hline I & 246 & 32.72 & 222 & 29.53 \\
\hline 2 & 90 & 11.97 & 70 & 9.31 \\
\hline 3 & 123 & 16.36 & 87 & 11.57 \\
\hline 4 & 94 & 12.50 & 96 & 12.77 \\
\hline 5 & 346 & 46.02 & 313 & 41.63 \\
\hline 6 & 482 & 64.11 & 555 & 73.82 \\
\hline 7 & 357 & 47.48 & 328 & 43.62 \\
\hline 8 & 112 & 14.90 & 86 & 11.44 \\
\hline 9 & 34 & 4.52 & 21 & 2.79 \\
\hline 10 & 68 & 9.04 & 50 & 6.65 \\
\hline 11 & 89 & 11.84 & 105 & 13.97 \\
\hline 12 & 155 & 20.62 & 151 & 20.08 \\
\hline 13 & 154 & 20.48 & 104 & 13.83 \\
\hline 14 & 170 & 22.61 & 124 & 16.49 \\
\hline 15 & 176 & 23.41 & 128 & 17.02 \\
\hline 16 & 179 & 23.81 & 134 & 17.82 \\
\hline 17 & 120 & 15.96 & 95 & 12.64 \\
\hline 18 & 101 & 13.43 & 84 & 11.17 \\
\hline 19 & 9 & 1.20 & 0 & 0 \\
\hline 20 & 211 & 28.06 & 163 & 21.68 \\
\hline
\end{tabular}

we can calculate capillary (c), arterial (a), and mixed $(\bar{v})$ blood $\mathrm{O}_{2}$ contents as follows:

$$
\begin{aligned}
\mathrm{CC}_{\mathrm{O}_{2}}= & (9 \times 1.37 \times 1.00)+(402.8 \times 0.003)= \\
& 13.54 \mathrm{ml} / 100 \mathrm{ml}\left(\mathrm{N} . \mathrm{B} .: \text { capillary } \mathrm{PO}_{2}\right. \\
& \left.=\text { alveolar } \mathrm{PO}_{2}=402.8 \mathrm{mmHg}\right) \\
\mathrm{Ca}_{\mathrm{U}_{2}}= & (9 \times 1.37 \times 0.81)+(46 \times 0.003) \\
& =10.13 \mathrm{ml} / 100 \mathrm{ml} \\
\mathrm{C}_{\mathrm{O}_{2}}= & \mathrm{Ca}_{\mathrm{O}_{2}}-3.5=6.63 \mathrm{ml} / 100 \mathrm{ml} \\
\dot{\mathrm{Q}} \mathrm{s} / \dot{\mathrm{Q}}= & \frac{13.54-10.13}{13.54-6.63}=49.4 \text { per cent. }
\end{aligned}
$$

\section{RESULTS}

Table I features the usual clinical laboratory measurements for the twenty patients investigated.

Table II shows both $\mathrm{A}-\mathrm{aDo}_{2}$ values obtained from the "clinical short cut" method and from the more sophisticated one.

Figure I shows how closely these two values were correlated $(r=0.98, p<0.001)$.

Table III shows, for a given patient, both pulmonary shunt values obtained from the "clinical short cut" method and from the more sophisticated one. Paired Student t-test gave no statistically significant difference between the values obtained from the "clinical short cut" method and from the more sophisticated one ( $p>0.05)$.

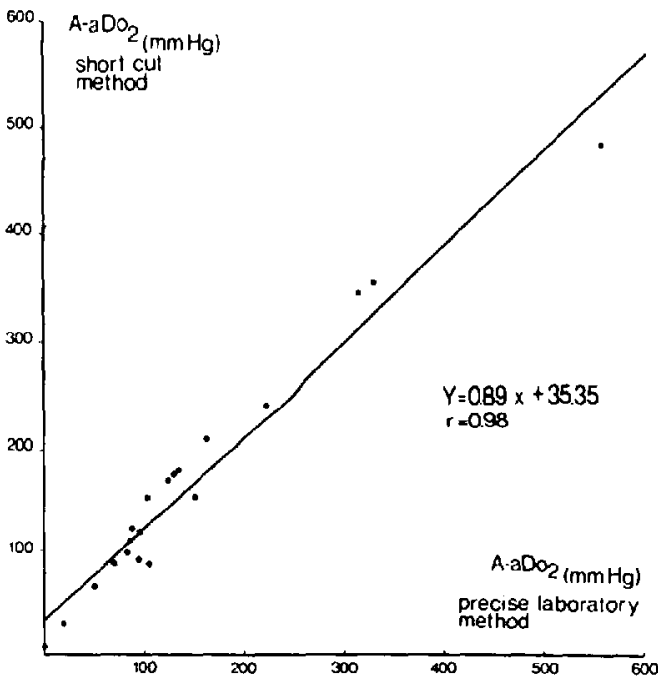

FIgURE 1 Correlation between A-aDo values.

Figure 2 shows how closely these two values were correlated $(r=0.87, p<0.01)$.

\section{Discussion}

$\mathrm{A}-\mathrm{aDO}_{2}$ and intrapulmonary shunt estimated with our "short cut" method are in close agreement with values obtained from a more sophisticated method. As a matter of fact, in 90 per cent of the cases the "short cut" method produced a quantitative estimation clinically equivalent to the value obtained by the precise laboratory method.

Furthermore, as we can see in patient \#9, the "clinical short cut" method might have a certain advantage over the precise laboratory estimation which requires a degree of collaboration from the patient when he is not on a respirator. This particular patient was semiconscious and uncooperative during the test. This could explain the discrepancy between the shunt values obtained by the two methods. In this instance we would be inclined to accept the "clinical short cut" result as being the true state of this patient.

It thus becomes possible for a clinician having available only arterial gases, haemoglobin and $\mathrm{F}_{\mathrm{O}_{2}}$ to be in a position to use alveoloarterial gradient and intrapulmonary shunt to make a diagnosis, follow the evolution and direct the treatment for his patient.

\section{Conclusion}

The proposed method of estimation is accurate and simple. The calculations may be done by 
TABLE III

Q́s/Q't VALues

\begin{tabular}{ccc}
\hline \hline & $\begin{array}{c}\text { Qss/Qt } \\
\text { "short cut" } \\
\text { method } \\
\text { (per cent) }\end{array}$ & $\begin{array}{c}\dot{\mathrm{Q} s} / \mathrm{Q} \mathrm{t} \\
\text { laboratory precise } \\
\text { method } \\
\text { (per cent) }\end{array}$ \\
\hline 1 & 31.0 & 30.6 \\
2 & 21.7 & 19.3 \\
3 & 20.7 & 9.6 \\
4 & 19.3 & 16.3 \\
5 & 48.2 & 56.8 \\
6 & 39.0 & 47.8 \\
7 & 49.6 & 48.5 \\
8 & 20.1 & 14.5 \\
9 & 20.4 & 0 \\
10 & 36.1 & 30.4 \\
11 & 19.8 & 19.9 \\
12 & 22.8 & 25.0 \\
13 & 20.2 & 21.4 \\
14 & 25.8 & 30.6 \\
15 & 25.1 & 20.7 \\
16 & 31.1 & 25.0 \\
17 & 29.8 & 13.0 \\
18 & 20.0 & 12.4 \\
19 & 14.6 & 14.5 \\
20 & 30.3 & 24.2 \\
\hline
\end{tabular}

hand or with a pocket calculator (appendix A), without the use of more sophisticated apparatus. $\mathrm{A}-\mathrm{aDO}_{2}$ and intrapulmonary shunt thus become available to any clinician.

\section{ACKNOWLEDGEMENTS}

The authors are grateful to Rachel Waugh, M.D., FRCP(C), and to Mrs. Angeline Lafontaine Alcaraz, A.R.T., for their helpful collaboration.

\section{REFERENCES}

1. TAllvik, R. Nomogram for Estimating Standard $\mathrm{PaO}_{2}$ and Alveolar-Arterial Gradient for Oxygen during ventilation with Room Air. Respiration 34: 118-120 (1977).

2. Gregory, I.C. Assessment of Van Slyke Manometric Measurements of Oxygen Content. J. Appl. Physiol. 34: 715-717 (1973).

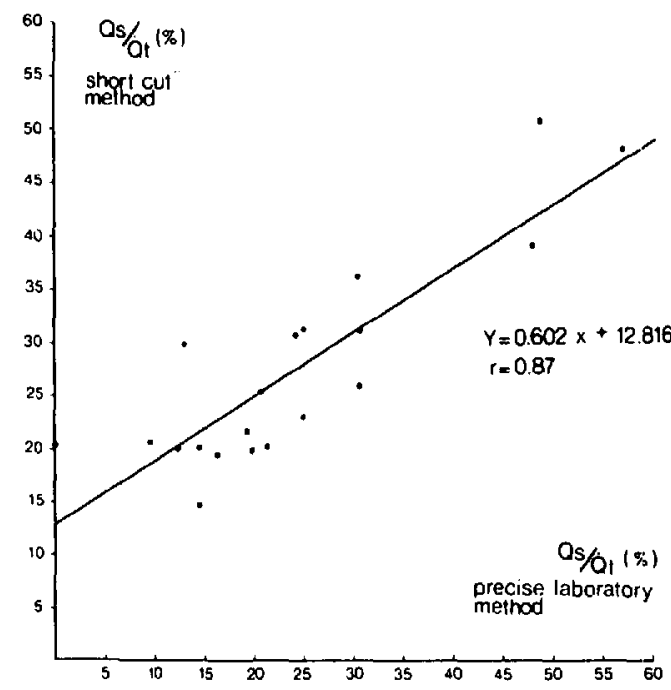

FiguRE 2 Correlation between intrapulmonary shunt values.

3. Rülz, B.C., TUCker, W.K. \& Kirby, R.R. A Program for Calculation of Intrapulmonary Shunts, Blood-Gas and Acid-Base Values with a programmable Calculator. Anesthesiology 42: 88-95 (1975).

4. Comroe, J.H., Forster, R.E., Dubois, A.B., Briscoe, A. \& Carlsen, E. The Lung. 2nd ed. Chicago, Year Book medical publishers, Inc. p. 339 (1968).

5. Comroe, J.H., Forster, R.E., Dubois, A., BrisCOE, A. \& Carlsen, E. The Lung. 2nd ed. Chicago. Year Book Medical Publishers, Inc. p. 125 (1968).

6. Comroe, J.H., Forster, R.E., Dubols, A.B., Briscoe, W.E. \& Carlsen, E. The Lung, 2nd ed. Chicago. Year Book medical Publishers, Inc. p. 344 (1968).

7. Harrison, R.A., Davison, R., Shapiro, B.A. Meyers, S.N. Reassessment of the Assumed A-V Oxygen Content Difference in the Shunt Calculation. Anesthesia and Analgesia 54: 198-202 (1975).

8. Severinghaus, J.W. Blood gas calculator. J. Appl. Physiol. 21: 1108-1116 (1966).

9. Dijkhuizen, P.A., Buursma, A., Fongers, T.M.E., Gerding, B., Oeseburg, B. \& Zijlstra, W.G. The Oxygen Binding Capacity of Human Haemoglobin (Hüfner's Factor Redetermined). Pflügers Arch. 369: 223-231 (1977).

\section{RÉSUMÉ}

La présente étude démontre, chez 20 patients, l'application d'une formule simple pour estimer l' $\mathrm{A}-\mathrm{aDO}_{2}$ et le shunt intrapulmonaire. Cette formule utilise les données normalement mesurées chez les patients qui présentent des troubles d'oxygénation. La corrélation entre les valeurs obtenues par la méthode simplifiée et celles découlant d'une méthode à la fois beaucoup plus précise et sophistiquée est statistiquement très valable.

\section{APPENDIX}

The following program will run in the programmable calculators TI 58 or TI 59 and will calculate the $\mathrm{A}-\mathrm{aDO}_{2}$ and the intrapulmonary shunt according to the 
approximation given in the article. It can easily be adapted to run in a HP-65 or any other HP programmable calculator.

When the program is inserted into the TI-58 or TI-59 programmable calculator the following steps should be followed:

Enter the $\mathrm{PO}_{2}$ and press on " $\mathrm{A}$ "; enter the saturation for this $\mathrm{Po}_{2}$ and press " $\mathrm{R} / \mathrm{S}$ ". We then enter the $\mathrm{PCO}_{2}$ and press " $\mathrm{B}$ ". When the $\mathrm{FI}_{\mathrm{O}_{2}}$ is keyed we press " $\mathrm{C}$ " and when $\mathrm{Hb}$ is entered we press " $\mathrm{D}$ ". The order of insertion for the different parameters has no importance but they must all be entered into the calculator.

When all information is furnished to the calculator, pressing " $E$ " will give first the $\mathrm{A}-\mathrm{aDo} \mathrm{O}_{2}$ in $\mathrm{mm} \mathrm{Hg}$ and pressing $\mathrm{R} / \mathrm{S}$ will give the intrapulmonary shunt in percentage.

Summary

\begin{tabular}{lccc}
\hline \hline \multicolumn{1}{c}{ Procedure } & Enter & Press & Display \\
\hline 1 Enter Program & & & \\
2 Measured $\mathrm{PO}_{2}$ & $\mathrm{Po}_{2}$ & $\mathrm{~A}$ & $\mathrm{PO}_{2}$ \\
3 Saturation from Severing- & & & \\
haus table (fraction) & $\mathrm{So}_{2}$ & $\mathrm{R} / \mathrm{S}$ & $\mathrm{So}_{2}$ \\
4 Measured PCO & $\mathrm{PCO}_{2}$ & $\mathrm{~B}$ & $\mathrm{Pco}_{2}$ \\
5 Inspired $\mathrm{O}_{2}$ (fraction) & $\mathrm{FI}_{\mathrm{O}_{2}}$ & $\mathrm{C}$ & $\mathrm{FI}_{\mathrm{O}_{2}}$ \\
6 Haemoglobin gm per cent & & & $\mathrm{Hb}$ \\
NB:2,3,4,5,6 in any order & $\mathrm{Hb}$ & $\mathrm{D}$ & $\mathrm{Hb}$ \\
7 & & $\mathrm{E}$ & $\mathrm{A}-\mathrm{aDo}$ \\
& & $\mathrm{R} / \mathrm{S}$ & Shunt (\%) \\
\hline
\end{tabular}

Program

\begin{tabular}{|c|c|c|c|c|}
\hline LBL & $\mathbf{E}$ & $\mathrm{RCL}$ & $=$ & ( \\
\hline A & FIX & 01 & STO & RCL \\
\hline STO & 2 & $=$ & 09 & 09 \\
\hline 01 & 7 & $\mathrm{R} / \mathrm{S}$ & RCL & - \\
\hline $\mathrm{R} / \mathrm{S}$ & 1 & 1 & 07 & $\mathrm{RCL}$ \\
\hline STO & 3 & & $x$ & 10 \\
\hline 05 & - & 3 & RCL & ) \\
\hline$R / S$ & RCL & 7 & 05 & $\div$ \\
\hline LBL & 02 & $\times$ & + & ( \\
\hline B & - & RCL & $\mathrm{RCL}$ & $\mathrm{RCL}$ \\
\hline STO & 7 & 04 & 01 & 09 \\
\hline 02 & 1 & $=$ & $x$ & - \\
\hline$R / S$ & 3 & STO & RCL & RCL \\
\hline LBL & $x$ & 07 & 08 & 11 \\
\hline C & ( & + & $=$ & ) \\
\hline STO & 1 & RCL & STO & $=$ \\
\hline 03 & - & 06 & 10 & $x$ \\
\hline $\mathrm{R} / \mathrm{S}$ & RCL & $x$ & - & 1 \\
\hline LBL & 03 & & 3 & 0 \\
\hline D & ) & 0 & . & 0 \\
\hline STO & $=$ & 0 & 5 & $=$ \\
\hline 04 & STO & 3 & $=$ & $\mathrm{R} / \mathrm{S}$ \\
\hline $\mathrm{R} / \mathrm{S}$ & 06 & STO & STO & \\
\hline LBL & - & 08 & 11 & \\
\hline
\end{tabular}

